\title{
TINGKAT PENERAPAN \\ RENCANA PELAKSANAAN PEMBELAJARAN \\ DALAM PELAKSANAAN PEMBELAJARAN DI KELAS \\ Suatu Studi Kasus di SMA Dian Harapan Jakarta
}

Juniriang Zendrato

juniriang.zendrato@uph.edu

FIP - Universitas Pelita Harapan

\begin{abstract}
ABSTRAK
Rencana Pelaksanaan Pembelajaran merupakan panduan mengajar yang disusun guru dalam rangka mencapai tujuan pembelajaran. Namun, sebagian besar guru belum menyadari arti pentingnya Rencana Pelaksanaan Pembelajaran ini. Oleh karena itu, penelitian ini bertujuan untuk mengetahui: faktor-faktor yang menjadi bahan pertimbangan guru saat menyusun Rencana Pelaksanaan Pembelajaran, kualitas penerapan Rencana Pelaksanaan Pembelajaran di kelas, dan tingkat penerapan Rencana Pelaksanaan Pembelajaran di dalam pelaksanaan pembelajaran di kelas. Penelitian ini merupakan studi kasus dan dilakukan di kelas 10 dan 11 SMA Dian Harapan Jakarta. Data dikumpulkan dengan empat macam teknik: (1) angket yang diberikan kepada guru dan siswa, (2) wawancara dengan guru dan kepala sekolah, (3) telaah dokumen RPP, dan (4) observasi kelas. Hasil penelitian menunjukkan bahwa faktor-faktor yang menjadi bahan pertimbangan guru saat menyusun Rencana Pelaksanaan Pembelajaran adalah karakteristik siswa, tujuan belajar, kegiatan belajar mengajar dan materi pelajaran. Tiga kualitas penerapan Rencana Pelaksanaan Pembelajaran di kelas: (1) pelaksanaan pembelajaran di kelas berjalan dengan lancar, (2) kegiatan yang tercantum dalam Rencana Pelaksanaan Pembelajaran tidak diterapkan di kelas, dan kegiatan yang tidak tercantum dalam Rencana Pelaksanaan Pembelajaran terjadi di kelas. Tingkat penerapan Rencana Pelaksanaan Pembelajaran di dalam kelas tergolong tinggi. Hal ini dapat dilihat dari persentase kegiatan dalam Rencana Pelaksanaan Pembelajaran yang diterapkan di kelas adalah sebesar $(81 \%)$. Oleh karena itu, pihak guru perlu terus membuka diri terhadap peningkatan kompetensi profesional guru.
\end{abstract}

Kata kunci: Rencana Pelaksanaan Pembelajaran

\section{PENDAHULUAN}

"Guru yang sukses adalah guru yang bisa memahami masalah akademik dan profesional, seperti mengerti motif siswa, kepribadian, kemampuan, gaya berpikir dan belajar, serta tingkah laku sosial siswa" (Djiwandono, 2002:3). Menjadi guru yang sukses merupakan suatu tujuan bagi setiap guru. Jika kesuksesan 
tercapai, guru akan merasa puas dengan apa yang mereka dapatkan di kelas. Akan tetapi, masih banyak guru yang belum menyadari aspek yang mempengaruhi keberhasilan pengajaran mereka walaupun telah banyak seminar mengenai hal tersebut diselenggarakan.

Kesuksesan mengajar dapat tercapai melalui kerjasama antara guru dan siswa. Namun demikian, guru adalah orang pertama yang menentukan kesuksesan pembelajaran. Awal kesuksesan itu dimulai dari perencanaan guru yang dibuat sebelum mengajar. Perencanaan itu tertuang dalam Rencana Pelaksanaan Pembelajaran (RPP). "RPP adalah rencana yang menggambarkan prosedur dan pengorganisasian pembelajaran untuk mencapai satu kompetensi dasar yang ditetapkan dalam Standar Isi dan dijabarkan dalam silabus" (Kunandar, 2007:240).

Kunandar (2007:240) menambahkan bahwa fungsi rencana pembelajaran ini adalah sebagai acuan bagi guru untuk melaksanakan kegiatan belajar mengajar (kegiatan pembelajaran) agar lebih terarah dan berjalan secara efektif. Oleh karena itu, persiapan yang dilakukan guru sebelum mengajar meliputi banyak hal yaitu persiapan tertulis, mental, situasi emosional yang ingin dibangun, lingkungan belajar yang produktif, termasuk meyakinkan pebelajar untuk mau terlibat secara penuh.

Di institusi pendidikan SMA Dian Harapan Jakarta, setiap guru dituntut untuk menyiapkan rencana pembelajaran sebelum mengajar. Rencana pembelajaran tersebut ditulis di dalam format RPP yang telah ditetapkan oleh sekolah. Berdasarkan wawancara formal saat pemberian feedback kepada guru setelah mengajar, ada beberapa masalah yang ditemukan oleh peneliti sehubungan dengan penyusunan RPP tersebut, yang antara lain sebagai berikut.

1. Guru memiliki jumlah jam mengajar yang tinggi sehingga RPP seringkali tidak tersiapkan sebelum mengajar.

2. Guru menulis RPP karena tuntutan administrasi sekolah. Oleh karena itu, faktor-faktor yang mempengaruhi pelaksanaannya di kelas kurang diperhatikan.

3. Guru berpendapat bahwa adanya RPP tidak menjamin tujuan pembelajaran akan tercapai.

4. Guru memiliki pemahaman bahwa RPP tidak selalu dapat diterapkan di kelas.

5. Guru merasa enggan untuk menjabarkan RPP secara detil mengingat banyak komponen yang harus ditulis untuk satu kali pembelajaran.

Fenomena di atas sangat menarik peneliti untuk mencari penyebab permasalahan tersebut. Saat menyusun RPP, guru diharapkan untuk mempertimbangkan tujuan pembelajaran, bahan ajar, alokasi waktu, dan karakteristik siswa. Namun demikian, RPP yang telah disusun secara sistematis sesuai dengan kriteria tidak menjadi jaminan bahwa tujuan pembelajaran akan 
tercapai.

Berdasarkan hal tersebut tampaklah bahwa mengajar tidak hanya mencakup aspek keilmuan dan teknologi saja, namun juga aspek seni. Hakikat seni mengajar terwujud dalam kenyataan bahwa aplikasi prinsip, mekanisme, dan alat yang terjadi secara unik memerlukan pertimbangan-pertimbangan situasional, bahkan penyesuaian-penyesuaian transaksional, yang banyak dituntun oleh naluri dan perasaan, tidak semata-mata bertolak dari dalih dan rumus (Simamora, 2008:75).

Walaupun hakikat seni mengajar telah diketahui oleh kalangan guru, namun keunikan ini belum banyak tergali. Berdasarkan pengamatan peneliti saat memberikan feedback kepada guru setelah mengajar, hampir seluruh guru yang ditemui telah berusaha untuk bersikap peka dan peduli terhadap pembelajaran di kelasnya. Namun ternyata tidak semuanya berhasil. Hal ini terbukti dari sikap menyalahkan guru terhadap siswa dan kondisi kelas ketika pembelajaran tidak berjalan sesuai dengan harapan. Dengan kata lain, tujuan instruksional yang dirancang tidak tercapai. Wardani (2006) berpendapat bahwa ketidakmampuan guru memahami masalah yang muncul dipengaruhi oleh terbatasnya wawasan tentang kependidikan, tujuan pembelajaran, prinsip-prinsip pembelajaran, respon siswa, dan situasi yang tidak terantisipasi.

Keengganan guru menuliskan evaluasi dan refleksi setelah mengajar juga menjadi salah satu faktor penghalang peningkatan kepekaan guru. Guru belum menyadari keuntungan dari penulisan evaluasi dan refleksi setelah mengajar. Padahal, penulisan evaluasi dan refleksi adalah kesempatan guru untuk melihat dan menganalisis proses pembelajarannya sendiri saat itu. Harapannya, guru akan menemukan jalan keluar atas permasalahan-permasalahan yang ia temui di dalam kelas.

Kesimpulannya, kemauan belajar guru dari pengalaman dan semangat untuk terus berlatih secara bertahap dan sistematis akan mempertajam kepekaan guru di dalam melihat gejala-gejala munculnya masalah di dalam kelas seperti yang diungkapkan oleh Wardani (2006). Kepekaan tersebut akan memampukan guru untuk mengambil setiap keputusan baik di dalam merancang maupun melaksanakan pembelajaran di kelas sehingga tujuan pembelajaran yang telah direncanakan tercapai seperti yang diharapkan.

\section{TINJAUAN PUSTAKA}

\section{Rencana Pelaksanaan Pembelajaran (RPP)}

RPP berfungsi sebagai acuan bagi guru untuk melaksanakan kegiatan belajar-mengajar (kegiatan pembelajaran) agar lebih terarah dan berjalan secara 
efektif dan efisien. Dengan kata lain, RPP ini akan menjadi panduan yang membantu guru mengontrol pelaksanaan pembelajarannya. Oleh karena itu, RPP hendaknya bersifat luwes (fleksibel) dan memberi kemungkinan bagi guru untuk menyesuaikannya dengan respon siswa dalam proses pembelajaran yang sesungguhnya. RPP yang tersiapkan sebelum mengajar akan mempermudah, memperlancar, dan meningkatkan hasil belajar. Selain itu, RPP yang disusun secara profesional, sistematis, dan berdaya guna, akan memampukan guru untuk melihat, mengamati, menganalisis, dan memprediksi program pembelajaran sebagai kerangka kerja yang logis dan terencana.

Callahn \& Clark (1982:17) berpendapat bahwa mengajar tanpa persiapan tertulis akan menghasilkan ketidakefektifan pembelajaran di dalam kelas karena guru tidak memikirkan secara detil apa yang akan dilakukan dan bagaimana melakukannya. Kutipan Callahn \& Clark di atas mengukuhkan pentingnya RPP. Dengan RPP, guru dapat mengorganisasikan kompetensi standar yang akan dicapai dalam pembelajaran secara lebih terarah. Kemp (1994) berpendapat bahwa RPP juga memberikan manfaat bagi banyak pihak. Manfaat tersebut antara lain sebagai berikut.

1) Administrator atau pengelola program akan mendapat bukti tentang proses belajar yang efektif dan efisien.

2) Perancang pengajaran akan mendapat bukti bahwa program yang dirancangnya memuaskan. Indikator terbaik adalah pencapaian semua tujuan program oleh siswa dalam batas waktu yang tepat.

3) Guru dapat melihat siswanya memperoleh semua kemampuan yang diharapkan dan dapat membina hubungan positif dengan siswa secara pribadi.

4) Siswa mendapatkan pengalaman belajar yang menyenangkan dan memuaskan.

Menyadari begitu pentingnya RPP dalam pelaksanaan pembelajaran, setiap guru harus memiliki paradigma bahwa perencanaan pembelajaran adalah suatu hal yang wajib dilakukan sebelum mengajar di kelas. Guru perlu mengetahui bahwa RPP berisi garis besar (outline) apa yang akan dikerjakan oleh guru dan peserta didik selama proses pembelajaran.

Di dalam menyusun RPP, guru membutuhkan pertimbangan yang cukup detil karena hal tersebut melibatkan banyak hal, seperti kemampuan guru, siswa, fasilitas, dsb. Oleh karena itu, RPP harus dipersiapkan dengan matang. Wardani (2006) mengidentifikasi beberapa faktor yang harus dipertimbangkan oleh guru saat merencanakan pembelajaran, yaitu: (1) siswa (kemampuan, minat, jumlah, dsb), (3) materi pelajaran, (4) guru sendiri (filosofi tentang pendidikan, kemampuan mengelola pembelajaran, kemampuan menerapkan metode tertentu, kebiasaan, dsb), dan (5) ruang, fasilitas, dan waktu yang tersedia. 
Saat mempertimbangkan faktor-faktor tersebut, guru harus mampu membuat keputusan. Keputusan yang dibuat oleh guru ketika merencanakan pembelajaran inilah yang disebut keputusan situasional. Perencanaan pembelajaran ini harus berorientasi pada terbentuknya dampak instruksional dan dampak pengiring. Dampak instruksional adalah tujuan-tujuan isntruksional yang membantu siswa menguasai pengetahuan dan keterampilan tertentu. Dampak pengiring adalah tujuan-tujuan pembelajaran yang membantu siswa menguasai sikap dan perilaku tertentu.

\section{Proses Pembelajaran}

RPP yang telah disusun akan diterapkan di dalam pelaksanaan pembelajaran di kelas. Pembelajaran adalah proses interaksi antara peserta didik dengan lingkungannya sehingga terjadi perubahan perilaku ke arah yang lebih baik (Kunandar, 2007). Dalam pembelajaran tugas guru yang paling utama adalah mengondisikan lingkungan agar menunjang terjadinya perubahan-perubahan perilaku bagi peserta didik. Hal tersebut juga diungkapkan oleh Wardani (2006) yang mengatakan bahwa seyogyanya guru selalu memanfaatkan setiap peluang untuk menumbuhkan berbagai dampak pengiring (nurturant effect) dan mencapai tujuan-tujuan intruksional (instructional effects) yang telah direncanakan. Oleh karena itu, RPP yang disusun dan diterapkan di kelas harus mampu membantu siswa untuk menguasai pengetahuan, ketrampilan dan sikap tertentu.

Briggs (1980) mengulas pendapat Gagne bahwa belajar sangat berkaitan erat dengan desain pembelajaran. Ia juga memaparkan teori pembelajaran Gagne yang meliputi tiga komponen:

1. Taksonomi tujuan pembelajaran yang mendefinisikan tipe-tipe kemampuan yang dapat dipelajari manusia.

2. Kondisi belajar internal dan eksternal yang berhubungan dengan penguasaan tiap kategori tujuan pembelajaran; dan

3. Sembilan peristiwa pembelajaran yang tiap peristiwanya memfasilitasi proses kognitif khusus selama belajar.

Tidak semua desain pembelajaran yang diterapkan di kelas akan berjalan lancar. Banyak faktor yang mempengaruhi pelaksanaan tersebut. Faktor-faktor tersebut ada yang berasal dari guru sendiri ada yang dari siswa. Namun demikian, tujuan pembelajaran yang telah ditetapkan menjadi fokus yang harus dicapai. Oleh karena itu, guru harus mampu menyesuaikan pelaksanaan pembelajaran dengan kondisi kelas. Keputusan inilah yang disebut keputusan transaksional. Menurut Wardani (2006) keputusan transaksional adalah keputusan yang dibuat guru ketika transaksi pembelajaran sedang terjadi, yaitu ketika pembelajaran sedang 
berlangsung. Ada beberapa hal yang perlu dipertimbangkan oleh guru ketika membuat keputusan ini yaitu: (1) wawasan kependidikan guru, (2) tujuan atau kompetensi yang ingin dicapai, (3) prinsip-prinsip pembelajaran, (4) respon siswa yang harus mampu dibaca oleh guru, dan (5) situasi yang tidak diantisipasi.

Transaksi pembelajaran yang dilakukan juga tidak selalu tepat dan membantu pencapaian tujuan pembelajaran. Hal ini juga dipengaruhi oleh berbagai faktor, diantaranya sebagai berikut.

1) Wawasan kependidikan yang mantap akan membuat guru peka terhadap halhal yang memerlukan penyesuaian dan mantap mengambil keputusan.

2) Pemahaman guru terhadap karakteristik siswa akan memudahkan guru mengantisipasi apa yang akan terjadi dan melakukan penyesuaian jika terjadi situasi yang menuntut perubahan.

3) Penguasaan substansi dan metodologi keilmuan mata pelajaran yang diampu akan menambah rasa percaya diri guru.

4) Penguasaan yang mantap tentang prisip-prinsipp pembelajaran yang mendidik akan membuat guru mempunyai landasan yang kuat tentang apa yang harus dia lakukan dalam menghadapai situasi yang berkembang dalam kelas.

5) Penguasaan dasar-dasar komunikasi dan keterampilan dasar mengajar akan memudahkan guru mengaktifkan dan memotivasi siswa.

6) Penguasaan prinsip-prinsip penilaian proses dan hasil belajar siswa akan memberikan wawasan yang mantap bagi guru ketika ia menghadapi situasi yang menuntutnya untuk mengambil keputusan transaksional.

Pengambilan keputusan transaksional dalam rangka mencapai tujuan pembelajaran tidak mudah untuk dilakukan walaupun ketrampilan pengambilan keputusan ini wajib dimiliki oleh guru (Semiawan dan Joni, 1993). Ketrampilan mengambil keputusan merupakan satu keterampilan berpikir yang memerlukan latihan untuk menguasainya. Dari segi keterampilan berpikir, pengambilan keputusan meliputi beberapa tahap. Tahap pertama adalah mengidentifikasi munculnya masalah. Tahap kedua adalah merumuskan secara jelas tujuan yang ingin dicapai sehingga adanya masalah tidak membelokkan kegiatan belajar dari tujuan yang telah ditetapkan. Tahap ketiga adalah menganalisis masalah.

\section{Pembelajaran bermakna}

Menurut Ausubel, faktor yang paling penting dalam mempengaruhi belajar adalah apa yang diketahui siswa. Ausubel menyampaikan satu alternatif model pengajaran yang disebut reception learning. Ahli-ahli teori reception learning menyarankan agar guru menyusun situasi belajar, memilih materi-materi yang tepat untuk siswa, dan kemudian menyampaikannya dalam bentuk pengajaran yang 
terorganisasi dengan baik, mulai dari yang umum ke hal-hal yang lebih terperinci (Djiwandono, 2002).

Di dalam pembelajaran bermakna ini, bahan pelajaran akan lebih mudah dipahami jika bahan itu dirasakan bermakna bagi siswa. Yang dimaksud dengan kebermaknaan adalah bahan yang disampaikan sesuai dengan sruktur kognitif, sruktur keilmuan, dan memuat keterkaitan.

Dapat disimpulkan bahwa siswa akan termotivasi belajar bila mereka melihat keterkaitan yang membentuk kesatuan pengetahuan dari materi-materi yang mereka pelajari. Di samping itu, penyampaian materi juga perlu dipikirkan oleh guru. Guru harus memberikan kesempatan pada siswa untuk mencari pengalaman belajarnya sendiri. Guru dapat menumbuhkan kreativitas siswa dengan menciptakan suasana yang kondusif dalam pertumbuhan ke arah perilaku yang positif (Semiawan, 1993).

Joni (1993) berpendapat bahwa guru dituntut berkognisi serta bermetakognisi dalam menyediakan kognisi serta membantu siswa belajar (meningkatkan proses kognisi maupun meta-kognisinya). Artinya, di satu pihak guru menggunakan kognisinya untuk merancang kegiatan belajar-mengajar. Proses perancangan ini membutuhkan keterampilan guru dalam membuat keputusan situasional sehingga seluruh tujuan pembelajaran akan tercapai. Saat kegiatan belajar mengajar yang sudah dirancang diimplementasikan, guru harus tetap mengamati perkembangan peristiwa belajar-mengajar dan memantau dampak setiap keputusan dan tindakan instruksionalnya terhadap belajar siswa. Guru dapat melakukan penyesuaianpenyesuaian yang diperlukan untuk mencapai tujuan yang telah ditetapkan (pengambilan keputusan transaksional).

Pembelajaran bermakna ini dapat diterapkan dengan pendekatan Cara Belajar Siswa Aktif (CBSA). Pendekatan ini bertujuan untuk melihat kegiatan belajar sebagai pemberian makna secara konstruktivistik terhadap pengalaman oleh pebelajar dan meletakkan dasar bagi pembentuk prakarsa dan tanggungjawab belajar para pebelajar ke arah belajar sepanjang hayat dengan dituntut asas "tut wuri handayani" (Joni, 1993).

\section{Kerangka berpikir}

Untuk melaksanakan pembelajaran di kelas, guru harus mempertimbangkan banyak hal yang meliputi berbagai pihak: (1) pihak guru sendiri, (2) pihak siswa, dan (3) pihak sekolah. Dari pihak guru, guru harus menguasai kompetensi profesional yang meliputi perencanaan sampai pelaksanaan pembelajaran di kelas. Guru juga memikirkan dampak perencanaan dan pengajarannya pada pihak siswa. Oleh karena itu, guru dituntut untuk peka terhadap respon siswa. Yang terakhir, 
guru harus mempertanggungjawabkan tugas dan tanggungjawab pelaksanaan pembelajarannya kepada pihak sekolah. Tingkat penerapan perencanaan tertulis guru dengan pelaksanaan pembelajarannya digambarkan dalam diagram 1.

Pada proses pelaksanaan, guru perlu akrab dengan kondisi kelas. Guru perlu fleksibel dalam mengendalikan proses pembelajaran sehingga tujuan pembelajaran tercapai. Namun demikian, proses pencapaian tujuan belajar tersebut ada kalanya tidak sesuai dengan apa yang telah dirancangkan. Oleh karena itu, guru perlu peka dengan respon siswa supaya dapat melakukan penyesuaian-penyesuaian di dalam kelas.

Tingkat penerapan RPP yang disusun guru dengan pelaksanaan pembelajaran di kelas akan terlihat kesesuaian perencanaan dengan pelaksanaan. Diharapkan guru menulis RPP dengan jelas dan rinci sehingga meminimalkan halhal yang tidak terantisipasi. Andaipun hal itu tejadi, guru harus menuliskan alasan pengambilan keputusan transaksionalnya ketika pembelajaran sedang berlangsung

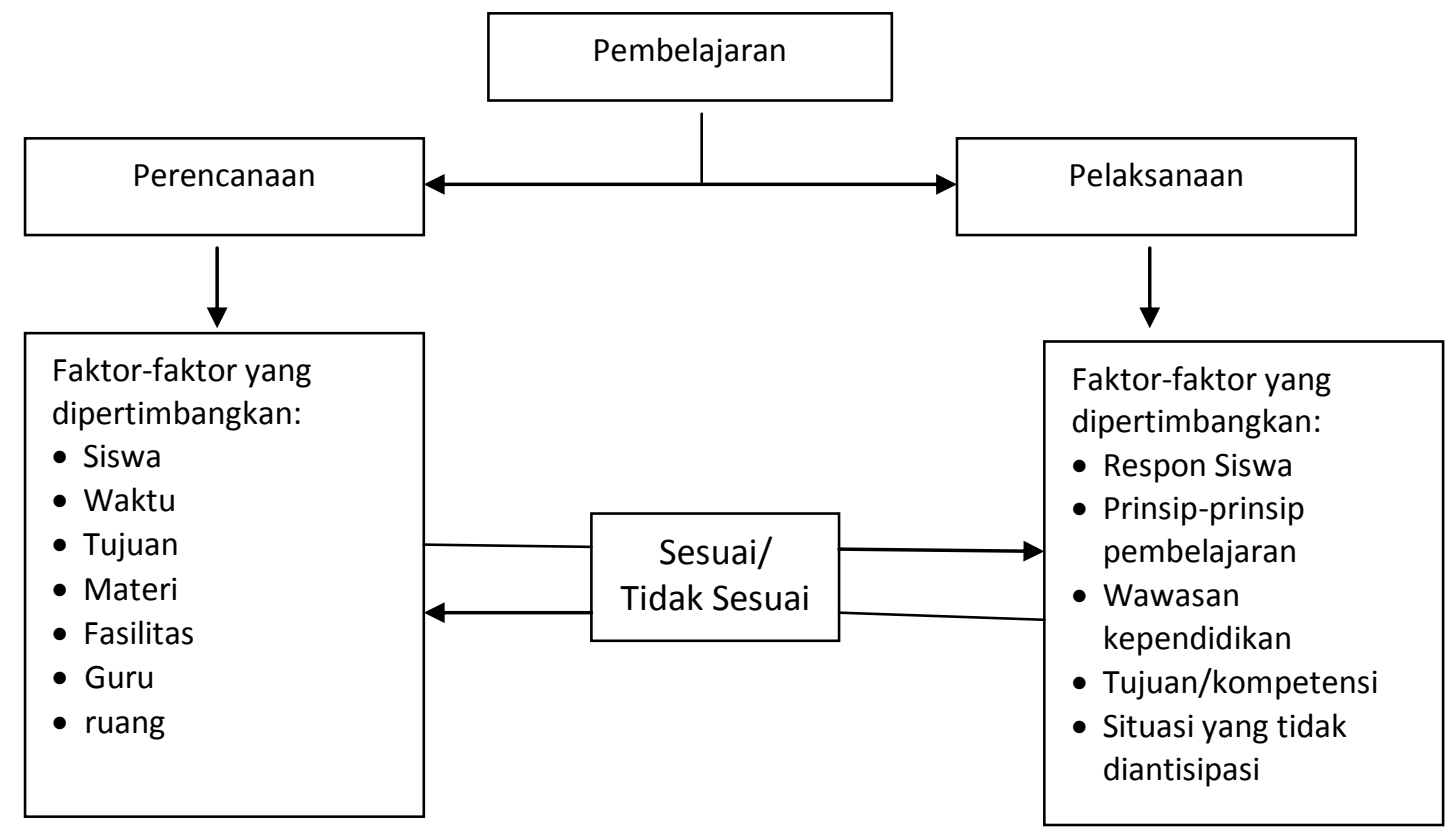

\section{Diagram 2.1 Tingkat Penerapan RPP dalam Pelaksanaan Pembelajaran di Kelas}




\section{METODE}

Penelitian ini merupakan penelitian studi kasus yang dilakukan di SMA Dian Harapan Jakarta. Penelitian ini dilakukan selama Maret - April 2009. Subjek yang diteliti sejumlah 15 orang yang terdiri dari guru berbagai bidang studi yang mengajar kelas 10 dan 11. Instrumen yang digunakan adalah lembar angket, panduan wawancara, dan panduan telaah dokumen. Teknik analisis data adalah dengan menggunakan deskriptif kualitatif.

Teknik analisis data untuk instrumen angket guru dan siswa adalah denngan menggunakan metode kuantitatif, sedangkan untuk instrumen observasi, angket, telaah dokumen, dan wawancara dilakukan dengan menggunakan metode kualitatif. Data dalam penelitian ini dikumpulkan melalui teknik observasi, angket, wawancara, dan telaah dokumen (tabel 1).

Tabel 1. Teknik dan Instrumen Pengumpulan Data

\begin{tabular}{|c|c|c|c|c|c|}
\hline No & Variabel & Indikator & Metode & Instrumen & Sumber data \\
\hline 1. & $\begin{array}{l}\text { Faktor yang } \\
\text { menjadi } \\
\text { bahan } \\
\text { pertimbangan } \\
\text { guru saat } \\
\text { menyusun } \\
\text { RPP }\end{array}$ & $\begin{array}{ll}\text { - } & \text { Siswa } \\
\text { - } & \text { Tujuan } \\
\text { - } & \text { Materi } \\
\text { - } & \text { Guru } \\
\text { - } & \text { Ruang, fasilitas, } \\
& \text { dan waktu }\end{array}$ & $\begin{array}{l}\text { - Angket } \\
\text { - Wawancara }\end{array}$ & $\begin{array}{l}\text { - Angket } \\
\text { - Panduan } \\
\text { Wawanca } \\
\text { ra }\end{array}$ & 15 Guru SMA \\
\hline 2. & $\begin{array}{l}\text { Penerapan } \\
\text { RPP yang } \\
\text { disusun oleh } \\
\text { guru }\end{array}$ & $\begin{array}{l}\text { - } \begin{array}{l}\text { Ada dalam RPP } \\
\text { dan ada dalam } \\
\text { penerapan }\end{array} \\
\text { - Ada dalam RPP } \\
\text { tetapi tidak ada di } \\
\text { dalam penerapan } \\
\text { - Tidak ada dalam } \\
\text { RPP tetapi ada } \\
\text { dalam penerapan }\end{array}$ & $\begin{array}{l}\text { - Observasi } \\
\text { - Wawancara }\end{array}$ & $\begin{array}{l}\text { - Panduan } \\
\text { Telaah } \\
\text { - Panduan } \\
\text { Wawanca } \\
\text { ra }\end{array}$ & $\begin{array}{l}\text { - } 15 \text { Guru } \\
\text { SMA } \\
\text { - Kegiatan } \\
\text { belajar/situa } \\
\text { si kelas }\end{array}$ \\
\hline 3. & $\begin{array}{l}\text { Tingkat } \\
\text { penerapan } \\
\text { RPP dalam } \\
\text { kelas }\end{array}$ & $\begin{array}{ll}\text { - } & \text { Sesuai } \\
\text { - } & \text { Tidak sesuai }\end{array}$ & $\begin{array}{l}\text { Telaah dokumen } \\
\text { RPP dan hasil } \\
\text { observasi }\end{array}$ & $\begin{array}{l}\text { Panduan } \\
\text { Telaah }\end{array}$ & $\begin{array}{l}\text { Hasil telaah } \\
\text { dokumen } 15 \\
\text { RPP dan } \\
\text { observasi } \\
\text { pelaksanaannya }\end{array}$ \\
\hline
\end{tabular}




\section{HASIL DAN PEMBAHASAN}

\section{Faktor-faktor yang menjadi bahan pertimbangan guru saat menyusun RPP}

Hasil penelitian mengenai faktor-faktor yang menjadi bahan pertimbangan guru saat menyusun RPP di SMA di Jakarta Barat didasarkan pada angket dan wawancara dengan 15 guru yang dilakukan setelah mereka menulis RPP. Hasilnya adalah karakteristik siswa (87\%), tujuan belajar (87\%), kegiatan belajar mengajar (87 \%), dan materi pelajaran $(80 \%)$ yang menjadi faktor yang paling banyak dipertimbangkan oleh guru. Faktor yang paling sedikit dipertimbangkan oleh guru adalah evaluasi belajar (60\%), media dan fasilitas (60\%), dan alokasi waktu (47\%). Faktor tambahan yang dipertimbangkan oleh guru adalah pengaturan tempat duduk (7\%), program sekolah (7\%), teknologi (7\%), dan kegunaan masa depan (7\%).

Faktor utama yang dipertimbangkan oleh guru saat menyusun RPP adalah karakteristik siswa (87\%), tujuan belajar (87\%), kegiatan belajar mengajar (87\%), dan materi pelajaran ( $80 \%)$ dengan alasan sebagai berikut.

Pertama, mereka mengetahui siswa yang akan mereka ajar, siswa IPA atau IPS. Kedua, para guru menetapkan tujuan belajar. Ketiga, materi merupakan hal penting yang perlu dipersiapkan oleh guru. Keempat, guru membutuhkan waktu yang cukup banyak untuk menyusun kegiatan belajar-mengajar yang interaktif dalam menyampaikan materi untuk mencapai tujuan belajar.

Sementara itu, faktor yang paling sedikit dipertimbangkan oleh guru adalah evaluasi belajar (60\%), media dan fasilitas (60\%), dan alokasi waktu (47\%) dengan alasan bahwa hal-hal tersebut dapat disusun setelah faktor utama ditentukan. Faktor tambahan yang dipertimbangkan oleh guru saat menyusun RPP adalah pengaturan tempat duduk (7\%), program sekolah (7\%), teknologi $(7 \%)$, dan kegunaan masa depan $(7 \%)$.

Temuan di atas sesuai dengan teori tentang keputusan situasional yaitu keputusan yang diambil oleh guru ketika merencanakan pembelajaran atau menyusun RPP. Pada saat menyusun RPP guru mempertimbangkan banyak faktor untuk mencapai tujuan pembelajarannya. Faktor-faktor tersebut saling berkaitan satu dengan yang lainnya. Faktor-faktor yang mempengaruhi kegiatan pembelajaran tersebut adalah (1) siswa (kemampuan, minat, jumlah, dsb), (2) tujuan yang ingin dicapai, (3) materi pelajaran, (4) guru sendiri (filosofi tentang pendidikan, kemampuan mengelola pelajaran, kemampuan menerapkan metode tertentu, kebiasaan, dsb), serta (5) ruang, fasilitas, dan waktu yang tersedia (Wardani, 2006). Kemampuan untuk membuat keputusan situasional juga merupakan salah satu kompetensi guru (Massofa, 2008). Oleh karena itu, guru wajib mengetahui dan menguasai keterampilan pengambilan keputusan tersebut. 
Dalam penelitian ini, guru mempertimbangkan faktor penyusunan RPP berdasarkan kebutuhannya untuk melaksanakan pembelajaran di kelas secara urut dan sistematis serta bermakna (memberikan kesempatan kepada siswa untuk memiliki pengalaman belajar) sehingga tercapai tujuan yang ditetapkan.

\section{Penerapan RPP di kelas}

Penerapan RPP di dalam kelas dilakukan melalui observasi dan wawancara terhadap 15 orang guru. Berdasarkan hasil observasi dan wawancara didapat tiga data tentang RPP guru dan penerapannya di kelas (tabel 2). Pertama, kegiatan yang ditulis dalam RPP diterapkan di kelas (25\%). Hal ini seluruh perencanaan tertulis guru diterapkan dengan lancar di kelas.

\section{Tabel 2. Penerapan RPP di kelas}

$\mathbf{N}=\mathbf{1 5}$

\begin{tabular}{|l|l|c|c|c|c|c|c|}
\hline \multirow{2}{*}{ No } & \multirow{2}{*}{ Kegiatan } & \multicolumn{6}{|c|}{ Penerapan RPP } \\
\cline { 3 - 8 } & & \multicolumn{2}{|c|}{ A } & \multicolumn{3}{|c|}{ B } & \multicolumn{2}{|c|}{ C } \\
\cline { 3 - 8 } & & $\mathbf{f}$ & $\mathbf{\%}$ & $\mathbf{f}$ & $\mathbf{\%}$ & $\mathbf{f}$ & $\mathbf{\%}$ \\
\hline 1 & Menyapa siswa & 1 & 10 & 0 & 0 & 14 & 93 \\
\hline 2 & Menyebutkan tujuan pembelajaran & 2 & 13 & 13 & 90 & 0 & 0 \\
\hline 3 & Menjelaskan agenda pembelajaran & 0 & 0 & 1 & 10 & 10 & 70 \\
\hline 4 & Memberikan Bell Assignment & 10 & 70 & 2 & 13 & 1 & 10 \\
\hline 5 & Membahas Bell Assignment & 5 & 33 & 1 & 10 & 3 & 20 \\
\hline 6 & Menyajikan materi & 6 & 40 & 1 & 10 & 1 & 10 \\
\hline 7 & Menggunakan media & 1 & 10 & 0 & 0 & 10 & 70 \\
\hline 8 & Mengembangkan pemberian model & 1 & 10 & 1 & 10 & 3 & 20 \\
\hline 9 & Memberikan latihan terbimbing & 8 & 53 & 4 & 30 & 2 & 13 \\
\hline 10 & Mengontrol kegiatan siswa & 4 & 27 & 0 & 0 & 10 & 70 \\
\hline 11 & Mengecek pemahaman siswa & 3 & 20 & 2 & 13 & 8 & 53 \\
\hline 12 & Memberikan latihan mandiri & 5 & 33 & 2 & 13 & 1 & 10 \\
\hline 13 & Menyimpulkan pelajaran & 2 & 13 & 2 & 13 & 4 & 30 \\
\hline 14 & Menutup sesi pelajaran & 1 & 10 & 0 & 0 & 13 & 87 \\
\hline & Rata-Rata & & $\mathbf{2 5}$ & & $\mathbf{1 6}$ & & $\mathbf{3 9}$ \\
\hline
\end{tabular}

\section{Keterangan:}

A.Ada dalam RPP dan ada dalam penerapan

B.Ada dalam RPP dan tidak ada dalam penerapan

C.Tidak ada dalam RPP tetapi ada dalam penerapan 
Kedua, kegiatan yang ditulis dalam RPP tidak diterapkan di kelas (16\%). Melihat respon siswa dan situasi kelas, guru dapat mengambil keputusan untuk tidak menerapkan beberapa kegiatan yang sudah direncanakan secara tertulis.

Alasan pengambilan keputusan tersebut dapat karena guru berfokus pada pencapaian tujuan belajar atau karena guru berfokus pada penyelesaian materi. Ketiga, kegiatan yang tidak ditulis dalam RPP tetapi muncul di dalam pelaksanaan pembelajaran di kelas (39\%). Hal ini dapat terjadi ketika guru melihat kebutuhan siswa pada saat itu yang memerlukan penyesuaian rencana sehingga pembelajaran tetap berjalan dengan lancar. Data tersebut disajikan pada Tabel 2.

Tertulis tidaknya kegiatan yang dilaksanakan di kelas di dalam RPP menandakan bahwa ada kegiatan-kegiatan pembelajaran yang sebelumnya tidak direncanakan tetapi dilakukan di dalam kelas. Ataupun sebaliknya, ada kegiatankegiatan pembelajaran yang tidak dipertimbangkan sebelumnya ternyata dilakukan di kelas karena melihat perkembangan situasi kelas. Pelaksanaan atau pembatalan kegiatan-kegiatan tersebut tentunya dalam rangka menjaga kondisi kelas agar tujuan pembelajaran tetap tercapai saat itu. Oleh karena itu, guru harus luwes dalam mengelola kelasnya.

Perbedaan-perbedaan itu terjadi karena alasan-alasan di bawah ini.

1. Banyak siswa yang mengajukan pertanyaan saat pembahasan berlangsung dan guru menganggap bahwa pertanyaan itu perlu dijawab sampai tuntas sehingga guru keluar dari rencana yang telah disusunnya.

2. Siswa tidak memberikan respon positif terhadap pembelajaran yang disampaikan sehingga guru harus mencari strategi mengajar lainnya dan hal ini membutuhkan waktu yang lebih panjang dari yang sudah direncanakan.

3. Kecepatan siswa dalam memahami materi yang disampaikan berbeda dari prediksi guru. Hal ini dapat dipengaruhi oleh kurangnya pemahaman guru terhadap karakteristik kelas atau situasi kelas yang tidak diantisipasi sebelumnya.

4. Siswa memerlukan waktu yang lebih panjang untuk mengerjakan latihan daripada alokasi yang telah ditetapkan guru. Hal ini pada umumnya terjadi karena ketidaktepatan prediksi guru terhadap bobot soal latihan yang diberikan dengan kemampuan siswa menyerap pelajaran.

5. Guru berorientasi pada penyelesaian materi. Hal ini mengakibatkan mereka tidak melakukan beberapa langkah kegiatan yang telah dipersiapkan saat mereka menemukan fakta bahwa siswa masih kesulitan dalam memahami materi yang disampaikan. Sebagai konsekuensinya, mereka membutuhkan waktu yang lebih lama untuk membantu siswa.

6. Program sekolah yang bersifat mendadak seperti latihan kebakaran di jam 
sekolah (yang tidak diberitahukan sebelumnya) membuat kelas tidak berjalan sebagaimana mestinya.

RPP merupakan panduan guru di dalam kelas tetapi bukan merupakan aturan kaku yang harus selalu diikuti. Sebagai bahan evaluasi guru terhadap perencanaan atau pelaksanaan di kelas, guru harus menuliskan catatan khusus bila kegiatan belajar mengajar tidak berjalan sesuai dengan rencana. Dengan demikian, guru mengetahui penyebab ketidaksesuaian rencana tertulis dengan pelaksanaan pembelajaran. Ketidaksesuaian rencana tertulis dengan pelaksanaan di dalam kelas bukan semata-mata merupakan kegagalan guru dalam mengajar tetapi sebagai alat evaluasi pelaksanaan pembelajarannya.

Dapat disimpulkan dari penelitian ini bahwa penerapan RPP di kelas dipengaruhi oeh respon siswa terhadap pembelajaran, situasi yang tidak diantisipasi dalam perencanaan seperti adanya latihan kebakaran (program sekolah), tujuan atau kompetensi yang akan dicapai oleh kelas yang memungkinkan guru untuk melakukan berbagai penyesuaian, dan kepuasan belajar siswa yang ditunjukkan melalui banyaknya pertanyaan yang disampaikan kepada guru.

Tingkat persentase tertinggi adalah pada kegiatan yang tidak tertulis dalam RPP tetapi muncul dalam pelaksanaan pembelajaran (39\%). Hal ini menggambarkan tingkat kecenderungan guru untuk sering mengambil keputusan transaksional dalam pelaksanaan pembelajaran. Namun demikian, ketepatan pengambilan keputusan ini masih perlu diteliti lebih lanjut.

\section{Tingkat penerapan RPP di dalam pelaksanaan pembelajaran di kelas}

Data tingkat penerapan RPP di kelas diperoleh dengan membandingkan hasil telaah dokumen RPP dan hasil observasi pelaksanaan (tabel 3). Data pada tabel 3 menunjukkan adanya dua keompok penerpan RPP di kelas, dengan rincian berikut:

1. Kegiatan dalam kelas sebanyak $81 \%$ dilaksanakan sesuai dengan RPP (81\%). Hal tersebut menunjukkan bahwa persiapan mengajar yang dilakukan guru memberi dampak positip terhadap pelaksanaan pembelajaran di kelas. Hal ini dapat terjadi karena guru sudah cukup mengenal karakteristik siswanya, kondisi kelas, ketersediaan fasilitas, dan kesesuaian tujuan belajar dengan kegiatan di kelas.

2. Pelaksanaan kegiatan belajar-mengajar dalam kelas sebanyak $10 \%$ tidak sesuai dengan RPP. Hal ini dipengaruhi oleh kondisi kelas yang berubah, ide spontan yang muncul saat mengajar, dan alokasi waktu yang berubah, karena diskusi yang panjang, siswa belum memahami materi yang disampaikan sehingga teknik mengajar yang harus diganti. 
Tabel 3. Tingkat Penerapan RPP dalam Pelaksanaan Pembelajaran di Kelas

\begin{tabular}{|l|l|c|c|c|c|c|}
\hline \multirow{2}{*}{ No } & \multirow{2}{*}{ Kegiatan } & \multicolumn{5}{|c|}{ Penerapan di kelas } \\
\cline { 3 - 7 } & & \multirow{2}{*}{ N } & \multicolumn{2}{|c|}{ Sesuai } & \multicolumn{2}{|c|}{$\begin{array}{c}\text { Tidak } \\
\text { Sesuai }\end{array}$} \\
\cline { 3 - 7 } & & & $\mathbf{f}$ & $\mathbf{\%}$ & $\mathbf{f}$ & $\mathbf{\%}$ \\
\hline 1 & Menyapa siswa & 1 & 0 & 0 & 1 & 100 \\
\hline 2 & Menyebutkan tujuan pembelajaran & 2 & 2 & 100 & 0 & 0 \\
\hline 3 & Menjelaskan agenda pembelajaran & 0 & 0 & 0 & 0 & 20 \\
\hline 4 & Memberikan Bell Assignment & 10 & 8 & 80 & 2 & 40 \\
\hline 5 & Membahas Bell Assignment & 5 & 3 & 60 & 2 & 0 \\
\hline 6 & Menyajikan materi & 6 & 6 & 100 & 0 & 0 \\
\hline 7 & Menggunakan media & 1 & 1 & 100 & 0 & 0 \\
\hline 8 & Mengembangkan pemberian model & 1 & 1 & 100 & 0 & 12 \\
\hline 9 & Memberikan latihan terbimbing & 8 & 7 & 88 & 1 & 0 \\
\hline 10 & Mengontrol kegiatan siswa & 4 & 4 & 100 & 0 & 0 \\
\hline 11 & Mengecek pemahaman siswa & 3 & 3 & 100 & 0 & 0 \\
\hline 12 & Memberikan latihan mandiri & 5 & 5 & 100 & 0 & 0 \\
\hline 13 & Menyimpulkan pelajaran & 2 & 2 & 100 & 0 & 0 \\
\hline 14 & Menutup sesi pelajaran & 1 & 1 & 100 & 0 & 0 \\
\hline & Rata-Rata & & & $\mathbf{8 1}$ & & $\mathbf{1 9}$ \\
\hline
\end{tabular}

Bila interval dibuat antara 0-100, maka nilai persentase 0-33 tergolong rendah, 34-67 tergolong sedang, dan 68-100 tergolong tinggi, maka dapat dikatakan bahwa tingkat penerapan RPP di dalam pelaksanaan pembelajaran di kelas tergolong tinggi $(81 \%)$. Artinya, perencanaan guru sangat membantu pelaksanaan pembelajaran di kelas. Semakin guru peka dengan kondisi kelas dan memahami karakteristik siswanya, semakin sesuai perencanaan tertulis yang dibuatnya dengan penerapan di kelas.

\section{SIMPULAN}

Berdasarkan hasil penelitian ini dapat diambil kesimpulan sebagai berikut.

1. Faktor utama yang dipertimbangkan oleh guru saat menyusun RPP adalah karakteristik siswa, tujuan belajar, kegiatan belajar-mengajar, dan materi pelajaran. 
2. Ada tiga pola yang ditemukan dalam penerapan RPP di kelas, yaitu: (a) kegiatan yang ditulis dalam RPP tetapi tidak diterapkan di kelas (25\%), (b) kegiatan yang ditulis dalam RPP tetapi tidak diterapkan di kelas (16\%), dan (c) kegiatan yang tidak ditulis dalam RPP tetapi muncul dalam kegiatan kelas (39\%).

3. Pelaksanaan pembelajaran di kelas yang sesuai dengan RPP (81\%) dan pelaksanaan pembelajaran di kelas yang tidak sesuai dengan RPP (19\%). Tingkat penerapan RPP di dalam pelaksanaan di kelas tergolong tinggi. Artinya, kegiatan yang sudah dirancang secara tertulis diterapkan di dalam kelas.

\section{DAFTAR PUSTAKA}

Briggs, L. J. 1980. Thirty years of instructional design: One man's experience. Educational Technology (hal 45-50).

Callahan, Joseph F. and Leonard H. Clark. (1988). Planning for competence. New York: Macmillan Publishing Co.

Djiwandono, Sri Esti Wuryani. 2002. Psikologi pendidikan. Jakarta: Penerbit PT Gramedia Widiasarana Indonesia.

Kemp, Jerrold E. 1994. Proses perancangan pengajaran. Bandung: Penerbit ITB.

Kunandar. 2007. Guru profesional: Implementasi Kurikulum Tingkat Satuan Pendidikan (KTSP) dan persiapan menghadapi sertifikasi guru. Jakarta: PT Raja GRafindo Persada.

Massofa. 2008. Profesi keguruan apa, mengapa, dan bagaimana pekerjaan profesi. Retrieved from https://massofa.wordpress.com/2008/01/24/profesikeguruan/

Semiawan, Conny R. dan T. Raka Joni. 1993. Pendekatan pembelajaran: acuan konseptual pengelolaan kegiatan belajar-mengajar di sekolah. Konsorsium Ilmu Pendidikan.

Simamora, Ns. Roymond H. 2008. Buku ajar kependidikan dalam keperawatan. Jakarta: Penerbit Buku Kedokteran EGC.

Wardani, I.G.A.K.. 2006. Pengambilan keputusan dalam layanan ahli pembelajaran. Naskah belum diterbitkan. Naskah untuk Lokakarya Penyempurnaan Kurikulum Program Pekerti/AA, Pusat Antar Universitas (PAU), Universitas Terbuka. 


\section{Lampiran}

RENCANA PELAKSANAAN PEMBELAJARAN

\begin{tabular}{|l|l|l|}
\hline Guru: & $\begin{array}{l}\text { Mata pelajaran: Sesi: Kelas: } \\
\text { Tanggal: }\end{array}$ \\
\hline $\begin{array}{l}\text { Tujuan Pembelajaran } \\
\text { (siswa mampu..., kata kerja/taksonomi } \\
\text { Bloom/integrasi alkitabiah/dapat } \\
\text { terukur/mudah dipahami) }\end{array}$ & Siswa mampu: & Waktu \\
\hline $\begin{array}{l}\text { Persiapan } \\
\text { (bersiap, menarik perhatian siswa/bell } \\
\text { assignment/pembuka) }\end{array}$ & & \\
\hline $\begin{array}{l}\text { Input/Pemberian model/Pengecekan } \\
\text { Pemahaman } \\
\text { (termasuk teks, halaman, judul, } \\
\text { metodologi, strategi - kecerdasan } \\
\text { majemuk/integrasi alkitabiah, } \\
\text { pembelajaran kooperatif, dll, alat bantu } \\
\text { mengajar, handout). }\end{array}$ & & \\
\hline $\begin{array}{l}\text { Latihan Terbimbing } \\
\text { (Kegiatan dalam kelas yang } \\
\text { menyediakan praktik tambahan) }\end{array}$ & & \\
\hline $\begin{array}{l}\text { Latihan Mandiri } \\
\text { (PR/Asesmen) }\end{array}$ & & \\
\hline $\begin{array}{l}\text { Refleksi } \\
\text { (Setelah mengajar - kesuksesan } \\
\text { pelajaran/informasi kebutuhan/siswa) }\end{array}$ & & \\
\hline
\end{tabular}

